\title{
Soil Fertility under Improved and Conventional Management Practices in Sanga, Kavrepalanchowk District, Nepal
}

\author{
Ram K. Shrestha \\ Ministry of Agriculture and Cooperatives, Singhadurbar, Kathmandu \\ $<$ rksathi05@yahoo.com>
}

\begin{abstract}
A study was carried out to compare the fertility of soils under improved soil management practice with that of prevailing conventional practice and to assess the farmers' perception on the improved practice in the upland farming system. The study was carried out in Nasikasthan Sanga of Kavrepalanchok district of Nepal. Soil samples were collected from fields under improved conventional practice. Samples were taken at 0-15 and 15-30 $\mathrm{cm}$ depths and were analyzed for various physico-chemical properties to compare the fertility status of the soils under both the practices. Altogether 68 farmers were interviewed to have information on farming practices and information pertinent to improved soil management practice being adopted by them. Results from soil physico-chemical analysis showed higher fertility of soils under improved practice in terms of more favorable $\mathrm{pH}$ level, contents of exchangeable bases, available phosphorus and soil organic matter compared to prevailing conventional soil management practice. Moreover, majority of the farmers believed that soil fertility and physical condition of their upland soils had improved and that the productivity of major upland crops had also increased after the adoption of improved soil management practice. Improved practice could play an important role in the sustainable management of upland soils in the mid hills of Nepal. It is however, desirable to conduct long-term research to further ascertain the effect of the practice on soil fertility of different soil types and land uses.
\end{abstract}

Key words: Improved soil management practice, organic matter, soil fertility, upland

\section{INTRODUCTION}

The overall status of inherent soil fertility is poor in most of the cultivated soils in the mid hills of Nepal. According to Shreier et al (1995) and Brown (1997) nitrogen and phosphorus levels in the soils are highly deficient with low organic matter content and supply. However, due to wide distribution of mica dominated bed rocks, potassium is abundantly available (Shreier 1999). Fertility decline of the mid hills soils have been reported by many authors (Carson 1992, Turton et al 1995, Schreier et al 1999, Neupane and Thapa 2001 and Pilbeam et al 2005). Major reasons leading to the 
decline in soil fertility are regarded as accelerated erosion, problems associated with red soils, reduced FYM/compost supply, and increased use of acid forming chemical fertilizers.

Two principal practices for maintaining soil fertility in the mid hills of Nepal are application of FYM and/or application of chemical fertilizers (Pilbeam et al 2005). FYM and compost are the main sources of plant nutrients and organic matter to the soil in the subsistence upland farming system of mid hills. However, there exist two issues related to the application of FYM and compost- problems of supplying an adequate amount of FYM and compost, and problems associated with the quality of FYM and compost. The supply of FYM and compost have been constantly declining owing to the reduced livestock herd size maintained by the farmers due to the shortage of labor, and gradually shrinking grazing lands and landholdings (Poudel and Thapa 2001). Preparation and use of compost, on the other hand, has also been marred by the above mentioned reasons together with reduced supply of plant residues and forest litter as its main ingredients. On the other hand, in the usual farmers' practice, farmers do not pay much attention to the proper decomposition of FYM leading to high $\mathrm{C} / \mathrm{N}$ ratio and poor quality of FYM. Exposure to direct sunlight of FYM and wastage of cattle urine also result in substantial nutrient loss. Only few farmers practice composting, but without following proper methods, yielding compost of poor quality.

With increasing cropping intensity and introduction of high nutrient demanding cash crops, increasing trend of chemical fertilizers application has been observed over the last couple of decades. However, due to the farmers' increased tendency of applying acid forming nitrogenous fertilizers only such as urea, improper combination of fertilizers and mistiming of application have resulted in adverse effects in soil environment leaving the fertility status of uplands of mid hills at stake.

Realizing the seriousness of the problem, the Government of Nepal has introduced a package of improved practices, through its agriculture extension system, aiming at correcting the above mentioned problems associated with application of FYM and compost, and chemical fertilizers for sustainable management of upland soils through the effective organic matter management. The improved practice imparts knowledge and skills on farmers about the preparation and utilization of FYM and compost to enhance the quality of FYM and compost and to ensure the preservation of otherwise being lost nutrients in the course of preparation and application of FYM and compost, and through uncollected livestock urine. On the other hand, under the improved practice, farmers are also provided with necessary knowledge and skills about the judicious use of chemical fertilizers. The improved practice is being disseminated among the farmers through the farmers' field-based training and demonstration activities.

It is indispensable to have the comprehensive assessment of agricultural technology being adopted by the farmers for its successful wider scale dissemination among the farming communities. Particularly, only a few studies have been conducted so far in determining the effectiveness of improved practice in improving soil fertility status of the upland soils in the mid hills. This paper attempts to assess the effectiveness of the improved soil management practice mainly through comparing the fertility status of soils under improved practice with that of other prevailing practices in one of the intensively cultivated upland fields of the mid hills of Nepal.

\section{MATERIALS AND METHODS}

\section{Study area}

The study was conducted in May-June, 2006 in the three settlements (ward number 2, 5 and 6) of 
Sanga Nasikasthan Village Development Committee (VDC) in Kavrepalanchok district of central Nepal. Situated at 1,480 to $1850 \mathrm{~m}$ from average sea level, Sanga lies about $25 \mathrm{~km}$ east of Kathmandu, the capital city. It occupies a total area of $918 \mathrm{~km}^{2}$. The VDC enjoys mainly subtropical climate but the southern part also experiences temperate climate. The temperature reaches as high as $34^{\circ} \mathrm{C}$ during summer (Jun-Aug) and as low as $2^{\circ} \mathrm{C}$ during winter (Dec-Feb) with annual precipitation of $1581 \mathrm{~mm}$. June to September is the main season for rainfall and receives $80 \%$ of the total annual precipitation. The VDC has mostly sloppy topography ( $70 \%$ of the total area). Total agricultural land is 850 ha with 550 ha upland area.

The soils of the VDC are broadly divided into red and non-red soils. The red soils correspond to Rhodustults and Haplustults formed, on quartzitic phyllite, while non-red soils correspond to Ustochrepts and Dystrochrepts, formed on phyllite, schist, quartzite, sandstone and siltstone, following the Soil Taxonomy of the USDA system (Brown et al 1999).

Major upland crops are maize (Zea mays L.), buckwheat (Fagopyrum esculentum L.), wheat (Triticum aestivum L.), rapeseed mustard (Brassica campestris, var. toria), potato (Solanum tuberosum L.), finger millet (Eleucine corocana L.) and vegetables. Likewise, rice (Oryza sativa L.), wheat and potato and vegetables are the major crops grown in the irrigated land.

The VDC has 1008 households with the population of 5,968 (Male-51.34\%, Female-48.66\%). Agriculture and livestock raising are the main occupation of the villagers.

\section{Soil sampling and analysis}

Soil samples were collected as per the sampling framework given in Table 1. Fields, at least for five years, under these practices were used for sampling. Samples were taken at the depths of 0-15 and $15-30 \mathrm{~cm}$. Composite samples were prepared from the three sub-samples taken at each sampling depth.

\section{Table 1. Soil sampling framework used for the collection of soil samples}

\begin{tabular}{|c|c|c|}
\hline Category & Soil management practice & $\begin{array}{l}\text { Representative cropping } \\
\text { pattern }\end{array}$ \\
\hline Improved & $\begin{array}{l}\text { Improved FYM/compost + NPK } \\
\text { fertilizers }(n=5)\end{array}$ & Maize-Potato/Vegetable \\
\hline Conventional & $\begin{array}{l}\mathrm{N} \text { fertilizers only + Conventional FYM (n } \\
=5)\end{array}$ & Maize-Mustard/Potato \\
\hline $\begin{array}{l}\text { High external } \\
\text { inputs- based }\end{array}$ & $\begin{array}{l}\text { Poultry litter + Conventional FYM + } \\
\text { Chemical fertilizer }(n=5)\end{array}$ & Vegetables/Potato-Maize \\
\hline Legume-based & NPK Fertilizers + Legumes $(n=5)$ & $\begin{array}{l}\text { Maize-Legumes- } \\
\text { Potato/Mustard }\end{array}$ \\
\hline Reference soils & Virgin forest soils $(n=5)$ & \\
\hline
\end{tabular}

The samples were air-dried and passed through a 2-mm mesh sieve to determine various physicochemical properties. Soil $\mathrm{pH}$ was determined in $\mathrm{H}_{2} \mathrm{O}$ or $1 \mathrm{M} \mathrm{KCl}$ with soil to solution ratio of 1:5 by the glass electrode method (denoted as $\mathrm{pH}_{\mathrm{w}}$ and $\mathrm{pH}_{\mathrm{k}}$ ). Total carbon (T-C) and total nitrogen (T-N) contents were determined with an NC analyzer (Sumika Chemical Analysis Service, Co., Tokyo, Sumigraph model NC-80). Available P content was determined by the Bray II method (Bray and Kurtz 1945). Exchangeable $\mathrm{Al}, \mathrm{H}$ and $\mathrm{NH}_{4}$ were extracted with $1 \mathrm{M} \mathrm{KCl}$. The contents of exchangeable acidity $(\mathrm{Al}+\mathrm{H})$ was determined by the titration method with $0.01 \mathrm{M} \mathrm{NaOH}$ and content of the exchangeable Al with $0.01 \mathrm{M} \mathrm{HCl}$. The content of exchangeable $\mathrm{H}$ was calculated as 
the difference between the values of the exchangeable acidity and exchangeable Al. The amount of exchangeable $\mathrm{NH}_{4}$ was determined by the Indophenol blue method (Mulvaney 1996). Cation exchange capacity (CEC) and the contents of exchangeable bases $(\mathrm{Ca}, \mathrm{Mg}, \mathrm{K}$ and $\mathrm{Na}$ ) were determined after successive extraction using $1 \mathrm{M} \mathrm{NH}_{4}-\mathrm{OAc}(\mathrm{pH} 7.0)$ and $10 \% \mathrm{NaCl}$. The amount of $\mathrm{NH}_{4}{ }^{+}$replaced by $\mathrm{Na}$ was determined by the steam distillation and titration method. Exchangeable base concentrations were determined by atomic absorption spectrometry $(\mathrm{Ca}, \mathrm{Mg}$, and $\mathrm{K})$ and by flame photometry (Na) (Shimadzu, Co., Kyot, AA-610S). Particle size distribution was determined by the pipette method. Bulk density was determined after oven drying at $105^{\circ} \mathrm{C}$ of core samples of undisturbed soils.

\section{Operational definition of soil management practices}

Improved soil management practice: This is an organic matter-based soil management practice. In this practice, FYM and compost are prepared and applied in the fields following the prescribed procedure. The prescribed procedure, which aims at nutrient preservation and quality enhancement of FYM and compost, and utilization of cattle urine as the important source of nitrogen for the crop, involves the following steps:

i) Protect from direct sunlight

ii) Protect from rain and run-on water

iii) Add cattle urine into the FYM or compost pit or use directly in the field as a source of nitrogen.

iv) Prepare compost using effective micro-organisms (EM) following prescribed procedure.

v) Incorporate the FYM or compost in the field during land preparation or keep in big heaps, covered with plastic or other covering materials, for later use.

Moreover, while fertilizing with chemical fertilizers, a combination of urea, diammonium phosphate (DAP) and muriate of potash (MOP) is used based on recommendation of soil test results.

Conventional soil management practice: In this practice, farmers used FYM prepared by their own conventional method. In usual farmers' conventional method of preparation, due to the farmers' ignorance about the proper method of preparation, FYM is not properly decomposed. Moreover, FYM is exposed to direct sunlight resulting in substantial nutrient loss. There is also no system of collection and utilization of cattle urine. Only inorganic fertilizer used is urea. This practice is the most common practice in subsistence farming of the study area.

High external inputs-based: In this case, the main source of plant nutrients was inorganic fertilizers which were supplemented by poultry litter and a little amount of conventional FYM. This was the popular soil management practice among commercial and semi commercial vegetable growers. This type of practice can be regarded as 'high external inputs' based soil management practice

Legumes-based: In this practice besides using inorganic fertilizers and conventional FYM, farmers incorporated one legume crop, mostly peas, in the yearly cropping cycle. In this soil management practice, legume crop serves two purposes, namely, as a source of nitrogen in the soil and as a cash crop as there was a good market for green peas in the local market. 


\section{Farmers' interview}

Information about farmers' perception on the improved soil management practices was obtained through the interview with the farmers adopting the improved practice. Out of the 115 farmers adopting the improved practice, 68 farmers $(60 \%)$ were randomly selected for the interview.

A set of structured questionnaire was used for the interview. Questionnaire was pre tested by interviewing one SSM practicing farmer from each ward. The final set of structured questionnaire mainly consisted of questions pertinent to household demographic information of the respondent, general information on farming practices, farmer's resource endowment, and farmers' perception about the role of improved practice in improving soil fertility status of upland fields and productivity of upland crops.

\section{Data analysis}

Statistical significance of difference in the soil physico-chemical parameters between the two soil management practices was determined through t-test using SPSS (SPSS Inc. 2002). The t-test was also used to compare productivity of upland crops before and after the adoption of improved practice. Other results of interview for both the practices were compared using simple arithmetic.

\section{RESULTS AND DISCUSSION}

\section{General aspects of soil fertility}

Results of physico-chemical analysis of the soils are given in Table 1 and 2. Relatively low T-C contents for both the soils might be due to the apparent fact that soil carbon pool increasingly diminishes when forest lands are converted into agricultural land for cultivation. The contents of T$\mathrm{C}$ and T-N of the soils under improved practice were higher than those under conventional practice. Comparatively higher T-C, T-N levels of soils under improved practice might be due to the return of organic manures and residues to the upland fields through the means of improved FYM and compost. Relatively low level of the T-N for both the practices reflects the fact that Nepalese soils, especially upland soils of the mid hills, mostly being deficient in nitrogen (Pandey 1996).

Table 1. Selected physico-chemical properties of soils studied $(0-15 \mathbf{c m})$

\begin{tabular}{|c|c|c|c|c|}
\hline \multirow{2}{*}{ Parameters } & \multicolumn{2}{|c|}{$\begin{array}{l}\text { Conventional practice }(\mathrm{n}= \\
5)\end{array}$} & \multicolumn{2}{|c|}{$\begin{array}{c}\text { Improved practice }(\mathrm{n}= \\
5)\end{array}$} \\
\hline & Ave & (sd) & Ave & $(\mathrm{sd})$ \\
\hline $\mathrm{pHw}^{* *}$ & 5.11 & $(0.35)$ & 5.88 & $(0.24)$ \\
\hline $\mathrm{pHk}^{* *}$ & 3.82 & $(0.18)$ & 4.85 & $(0.34)$ \\
\hline $\mathrm{EC}$ & 6.33 & 1.68 & 8.83 & 3.19 \\
\hline Exchangeable $\mathrm{H}$ & 0.30 & 0.34 & 0.07 & 0.01 \\
\hline Bulk Density, g cm-3 & 1.15 & $(0.05)$ & 1.20 & $(0.01)$ \\
\hline Total C*, g kg-1 & 9.40 & (1.07) & 12.34 & $(1.65)$ \\
\hline Total $\mathrm{N}^{*}, \mathrm{~g} \mathrm{~kg}-1$ & 0.99 & $(0.11)$ & 1.34 & $(0.21)$ \\
\hline $\mathrm{C} / \mathrm{N}$ & 9.54 & $(0.60)$ & 9.24 & $(0.30)$ \\
\hline Mineral N, g kg-1 & 69.46 & $(14.35)$ & 129.41 & $(69.46)$ \\
\hline NH4-N, cmolc kg-1 & 0.05 & $(0.01)$ & 0.05 & $(0.01)$ \\
\hline Available $\mathrm{P}^{* *}, \mathrm{mg} \mathrm{kg}-1$ & 14.13 & $(3.58)$ & 272.91 & $(61.06)$ \\
\hline $\begin{array}{l}\text { Exchangeable } \mathrm{Ca}^{* *} \text {, cmolc } \\
\mathrm{kg}-1\end{array}$ & 1.87 & $(1.28)$ & 4.43 & $(1.06)$ \\
\hline
\end{tabular}




\begin{tabular}{|c|c|c|c|c|}
\hline \multirow{2}{*}{ Parameters } & \multicolumn{2}{|c|}{$\begin{array}{l}\text { Conventional practice }(\mathrm{n}= \\
5)\end{array}$} & \multicolumn{2}{|c|}{$\begin{array}{c}\text { Improved practice }(\mathrm{n}= \\
5)\end{array}$} \\
\hline & Ave & (sd) & Ave & $(\mathrm{sd})$ \\
\hline $\begin{array}{l}\text { Exchangeable } \mathrm{Mg} * * \text {, cmolc } \\
\text { kg-1 }\end{array}$ & 0.42 & $(0.17)$ & 1.30 & $(0.28)$ \\
\hline Exchangeable $\mathrm{K}$, cmolc kg-1 & 0.21 & $(0.09)$ & 0.45 & $(0.26)$ \\
\hline $\begin{array}{l}\text { Exchangeable Na, cmolc kg- } \\
1\end{array}$ & 0.05 & $(0.02)$ & 0.05 & $(0.02)$ \\
\hline Sum bases* & 1.99 & $(1.80)$ & 5.00 & $(1.66)$ \\
\hline Base saturation, $\%$ & 27.26 & $(25.89)$ & 54.07 & $(17.91)$ \\
\hline $\mathrm{CEC}^{*}$, cmolc kg-1 & 7.39 & $(1.14)$ & 9.30 & $(0.91)$ \\
\hline ECEC* ${ }^{*}$ cmolc kg-1 & 2.66 & 1.49 & 5.02 & 1.64 \\
\hline $\begin{array}{l}\text { Exchangeable } \mathrm{Al}^{*} \text {, cmolc } \\
\text { kg-1 }\end{array}$ & 0.68 & $(0.46)$ & 0.02 & $(0.04)$ \\
\hline Al Saturation* & 32.90 & $(23.42)$ & 0.67 & $(1.18)$ \\
\hline Clay*, \% & 9.14 & $(2.93)$ & 18.97 & $(7.68)$ \\
\hline Silt, $\%$ & 18.39 & $(3.12)$ & 18.24 & $(2.24)$ \\
\hline Sand, $\%$ & 72.47 & $(3.13)$ & 62.79 & $(9.43)$ \\
\hline
\end{tabular}

Sum bases, exchangeable $\mathrm{Ca}+\mathrm{Mg}+\mathrm{K}+\mathrm{Na}$; base saturation, sum bases/CEC X 100;

ECEC (effective CEC), exchangeable $\mathrm{Ca}+\mathrm{Mg}+\mathrm{K}+\mathrm{Na}+\mathrm{Al}$; Al saturation;

exchangeable Al/ECEC X 100. *, **, Indicate significant differences between the two soil management practices at $5 \%$ and $1 \%$ level of significance respectively using t-test.

Relatively low CEC levels were found which are probably associated with the dominance of kaolinitic clays in the highly weathered soil minerals. Shah and Schreier (1995) described the reasons for low cation exchange capacity in Jhikhu Khola watershed, one of the typical watersheds in the mid hills of Nepal, as the result of inherited bedrock conditions (sandstone, siltstone, quartzite), and extensive weathering leaving kaolinite as the dominant clay minerals in these soils. For them, the low level of soil organic matter resulted from the historic losses of organic matter due to soil erosion, crop removal and litter collection was the another cause for the low exchange capacity of the soils. Comparatively higher CEC values for soils under improved management are

Table 2. Selected physico-chemical properties of poils studied $(15-30 \mathrm{~cm})$

\begin{tabular}{lcccc}
\hline \multirow{2}{*}{ Parameters } & \multicolumn{3}{c}{ Conventional practice $(\mathrm{n}=5)$} & \multicolumn{2}{c}{ Improved practice $(\mathrm{n}=5)$} \\
\cline { 2 - 5 } & Ave & $(\mathrm{sd})$ & Ave & $(\mathrm{sd})$ \\
\hline $\mathrm{pHw}^{* *}$ & 4.76 & $(0.37)$ & 5.86 & $(0.39)$ \\
$\mathrm{pHk}^{*}$ & 3.78 & $(0.17)$ & 4.59 & $(0.47)$ \\
EC* & 3.78 & $(1.00)$ & 6.12 & $(1.75)$ \\
Exchangeable H & 0.16 & $(0.04)$ & 0.09 & $(0.03)$ \\
Bulk density, g cm-3 & 1.21 & $(0.07)$ & 1.30 & $(0.06)$ \\
Total C*, g kg-1 & 5.41 & $(1.43)$ & 7.50 & $(0.88)$ \\
Total N**, g kg-1 & 0.61 & $(0.09)$ & 0.88 & $(0.12)$ \\
C/N & 8.93 & $(1.24)$ & 8.50 & $(0.37)$ \\
Mineral N, g kg-1 & 39.25 & $(8.66)$ & 53.07 & $(16.58)$ \\
NH4-N *, cmolc kg-1 & 0.05 & $(0.01)$ & 0.03 & $(0.01)$
\end{tabular}




\begin{tabular}{lrrrr} 
Available P, mg kg-1 & 4.73 & $(1.70)$ & 72.88 & $(26.45)$ \\
Exchangeable Ca**, cmolc kg-1 & 1.30 & $(1.72)$ & 3.21 & $(1.17)$ \\
Exchangeable Mg **, cmolc kg-1 & 0.27 & $(0.11)$ & 1.00 & $(0.36)$ \\
Exchangeable K, cmolc kg-1 & 0.11 & $(0.04)$ & 0.22 & $(0.12)$ \\
Exchangeable Na, cmolc kg-1 & 0.04 & $(0.02)$ & 0.05 & $(0.01)$ \\
Sum bases* & 1.72 & $(1.79)$ & 4.48 & $(1.63)$ \\
Base saturation, \% & 22.97 & $(24.91)$ & 56.70 & $(22.97)$ \\
CEC, cmolc kg-1 & 7.74 & $(1.53)$ & 8.02 & $(1.23)$ \\
ECEC, cmolc kg-1 & 3.32 & $(1.20)$ & 4.51 & $(1.59)$ \\
Exchangeable Al *, cmolc kg-1 & 1.63 & $(0.25)$ & 0.04 & $(0.04)$ \\
Al Saturation* & 54.26 & $(29.73)$ & 1.21 & $(1.48)$ \\
Clay*,\% & 10.69 & $(2.11)$ & 19.92 & $(7.24)$ \\
Silt, \% & 19.18 & $(2.72)$ & 19.04 & $(2.68)$ \\
Sand, \% & 70.13 & $(3.05)$ & 61.04 & $(9.37)$ \\
\hline
\end{tabular}

Sum bases, exchangeable Ca $+M g+K+N a$; base saturation, sum bases/CEC X 100;

ECEC (effective CEC), exchangeable $\mathrm{Ca}+\mathrm{Mg}+\mathrm{K}+\mathrm{Na}+\mathrm{Al}$; Al saturation;

exchangeable Al/ECEC X 100. *, **, Indicate significant differences between the two soil management practices at $5 \%$ and $1 \%$ level of significance respectively using $t$ - test.

attributable to high clay content of these soils. And, in case of surface soils, higher levels of soil organic matter derived from enhanced quality and quantity of FYM/compost may also have contributed to the higher $\mathrm{CEC}$ values. $\mathrm{CEC}$ is potential capacity of cation retention measured at $\mathrm{pH}$ 7. So, this does not reflect field $\mathrm{pH}$ condition. Effective CEC (ECEC) values for the both of soils were much lower than the respective CEC values. It suggests the contribution of negative charges derived from clay minerals to the level of the CEC and that predominance of permanent negative charges of clay minerals under acidic conditions. Moreover, permanent negative charge of soils under improved management might have been derived more from the increased input of improved FYM or compost leading to comparatively higher CEC values.

The results showed soils under both management systems to be acidic. This finding is consistent with the previous findings in the context of the mid hills of Nepal (Shreier et al 1999, Brown et al 1999). The general soil acidity in the mid hills comes from mainly two sources, namely, dominance of quartzite parent materials and increasing use of acidifying fertilizers like ammonia and urea. Negative consequences of continuous application of acidifying fertilizers have been also reported elsewhere. In Northwest Nigeria high rates of application of acidifying mineral fertilizers over extended periods resulted $\mathrm{pH}$ dropping to below 5 (Kyiogwom et al 1998). However, soils improved management practice showed less acidic condition. Comparatively more favorable $\mathrm{pH}$ in this soils compared to soils under conventional practice may be attributed to the use of good quality FYM or compost and use of combination of NPK fertilizers.

Relatively, low exchangeable Mg level in both the soils was probably the impact of inherent parent materials such as sandstone, siltstone and quartz. Relatively favorable exchangeable $\mathrm{K}$ values are expected to be the result of wide distribution of mica within the parent material (Shreier et al 1999). Higher contents of exchangeable $\mathrm{Ca}$ and $\mathrm{Mg}$ were observed in improved practice than the conventional one, which are attributable to the judicious use of chemical fertilizers and use of enhanced quantity and quality of FYM and compost in the former one. Moreover, the variation in the level of exchangeable bases in these two soils was probably also due to the influence of 
respective $\mathrm{pH}$ and $\mathrm{CEC}$ values of these soils that in turn, can be expected to be affected by soil management practices and soil texture.

Improved practice soils were free from potential Al toxicity with only traces of Ex Al. Conventional practice soils, on the other hand, were found to be more vulnerable for potential Al toxicity with exchangeable $\mathrm{Al}$ value of 0.68 and $1.63 \mathrm{cmol}_{\mathrm{c}} \mathrm{kg}^{-1}$ for the surface and sub-surface soils, respectively. Importantly, considering critical Al saturation of $>20$ percent for optimum maize yield (Juo and Franzluebbers 2003) and the maize being the main upland crop in the study area, conventional practice soils with Al saturation of 54.2 may be regarded as unsuitable for maize cultivation.

The two soils were found greatly varied with available P level. Low available P contents for conventional soils could be ascribed to the lack of $\mathrm{P}$ source as fertilizer and their highly acidic condition. Moreover, use of acidifying fertilizer like urea alone also might have affected decreasing $\mathrm{pH}$ and the resulting comparatively lower $\mathrm{P}$ level. This is because of increasing $\mathrm{P}$ unavailability in the soils with strongly acidic reaction. Other studies also reported the similar findings in the soils of the mid hills of Nepal (Shreier et al 1999 and Westarp et al 2004). One experiment conducted in cotton soil revealed that phosphorus use efficiency was double $\left(11.2 \mathrm{~kg} \mathrm{ha}^{-1}\right)$ at soil $\mathrm{pH}$ between $\mathrm{pH}$ 6.0 and 7.0 as compared to the amount at soil $\mathrm{pH}$ 5.09. On the other hand, a high level of available $\mathrm{P}$ in improved practice soils was probably due to the fertilization effects of DAP-a P containing fertilizer and an increased rate of good quality FYM and compost. These results, however, somewhat contradicted with the fact that problem of P absorption in rain-fed soils (Shreier et al 1999) and mid hills soils to be generally deficient in available P (Pandey 1996, Shreier et al 1999, Westarp et al 2004). Pierzynski et al (1994) also reported that in general, the acidic nature of soils and inherited low P-levels influence the availability of phosphorus in the Hindu Kush Himalaya region.

Higher clay content of improved practice soils was found which seemed to have resulted due to the difference in inherent soil types and might be partially responsible for the differences in other physico-chemical properties between these two soils.

\section{Comprehensive evaluation of improved and conventional practice in relation to soil fertility}

Different variables pertinent to soil physico-chemical properties discussed in preceding section may also be correlated with each other and so may not be independent of each other. Principal component analysis (PCA) provides a way of transforming large numbers of possibly correlated variables into smaller numbers of uncorrelated variables called principal components. With PCA, number of variables of the data set is reduced but most of the original variability in the data is retained.

Variables analysed in PCA were $\mathrm{pH}_{\mathrm{w}}, \mathrm{pH}_{\mathrm{k}}, \mathrm{T}-\mathrm{C}, \mathrm{T}-\mathrm{N}, \mathrm{C} / \mathrm{N}, \mathrm{NH}_{4}-\mathrm{N}$, available $\mathrm{P}$, exchangeable $\mathrm{Ca}$, $\mathrm{Mg}$ and $\mathrm{K}, \mathrm{CEC}$, exchangeable $\mathrm{Al}, \mathrm{ECEC}, \mathrm{Al}$ saturation, bulk density clay, silt and sand content and. The PCA could extract four principle components, PC 1, PC 2 and PC 3 and PC 4 (Table 3). All the PCs collectively explained 90\% variation in the data. PC 1 showed high factor loading for most of the variables studied. It has contributed $63 \%$ to the variation in the data having variables, $\mathrm{pH}$, Exch. bases, SOM, clay content, available P, etc. with high positive factor loading and exchangeable Al, Al saturation and sand content as variables with high negative factor loading (Table 3). Likewise, PC 2 could explain only $11.4 \%$ variation having variables, $\mathrm{NH}_{4}-\mathrm{N}$ and silt with high positive and negative factor loading respectively. PC 3 and PC 4 did not show any variable with high factor loading $(>70 \%)$. 
Figure 1 shows the PC ordination of the first two principal components, with the data points grouped according to the soil management practice. The distribution of the data points in the ordination diagram shows high propensity of improved practice soils for PC 1 indicating clay soils with higher fertility status compared to conventional practice soils. Conventional practice soils, on the other hand, showed relatively high inclination towards PC 2 but at the same time very low inclination for all other fertility parameters described by PC 1 indicating light and less fertile soils. Distribution of data points also indicates more variation in data of improved practice than conventional practice. Thus, improved practices showed preferable properties of soil fertility for the crop production compared to conventional practice soils.

Table 3. Principle component analysis (PCA) of the variables studied for the surface soils $(0-15 \mathrm{~cm})$ in different soil management practices

\begin{tabular}{lrrrr}
\hline \multirow{2}{*}{ Parameters } & \multicolumn{3}{c}{ Factor loadings } \\
\cline { 2 - 5 } pHw & PC 1 & PC 2 & PC 3 & PC $~$ \\
pHk & 0.78 & -0.51 & -0.14 & 0.26 \\
Bulk density & 0.97 & -0.14 & 0.03 & 0.10 \\
T-C & 0.72 & -0.01 & 0.35 & -0.19 \\
T-N & 0.90 & 0.16 & 0.30 & 0.12 \\
C/N & 0.95 & 0.15 & 0.16 & -0.02 \\
CEC & -0.64 & -0.05 & 0.50 & 0.53 \\
Exchangeable Ca & 0.71 & 0.11 & 0.29 & 0.33 \\
Exchangeable Mg & 0.85 & 0.05 & -0.31 & -0.32 \\
Exchangeable K & 0.95 & -0.10 & 0.00 & 0.21 \\
Exchangeable Al & 0.80 & 0.44 & 0.07 & 0.15 \\
ECEC & -0.80 & 0.19 & 0.52 & -0.14 \\
Al saturation & 0.91 & 0.12 & -0.15 & -0.25 \\
NH4-N & -0.83 & 0.12 & 0.46 & -0.11 \\
Available P & -0.14 & 0.76 & -0.35 & 0.36 \\
Clay & 0.80 & -0.39 & 0.03 & 0.39 \\
Silt & 0.82 & -0.07 & 0.39 & -0.31 \\
Sand & 0.37 & 0.82 & -0.07 & 0.09 \\
Contribution, \% & -0.85 & -0.19 & -0.33 & 0.25 \\
\hline
\end{tabular}

\section{Assessment of appropriateness of 'improved FYM/compost' technology from farmers' perspectives}

Improvement in soil fertility and surface hardness: Sixty percent of farmers interviewed believed that fertility of their upland soils had been improving since the adoption of improved practice. Such farmers cited combined use of NPK fertilizers and improvement in quality of FYM and compost as the major reasons. However, rest expressed that they did not experience any change in the overall fertility. 


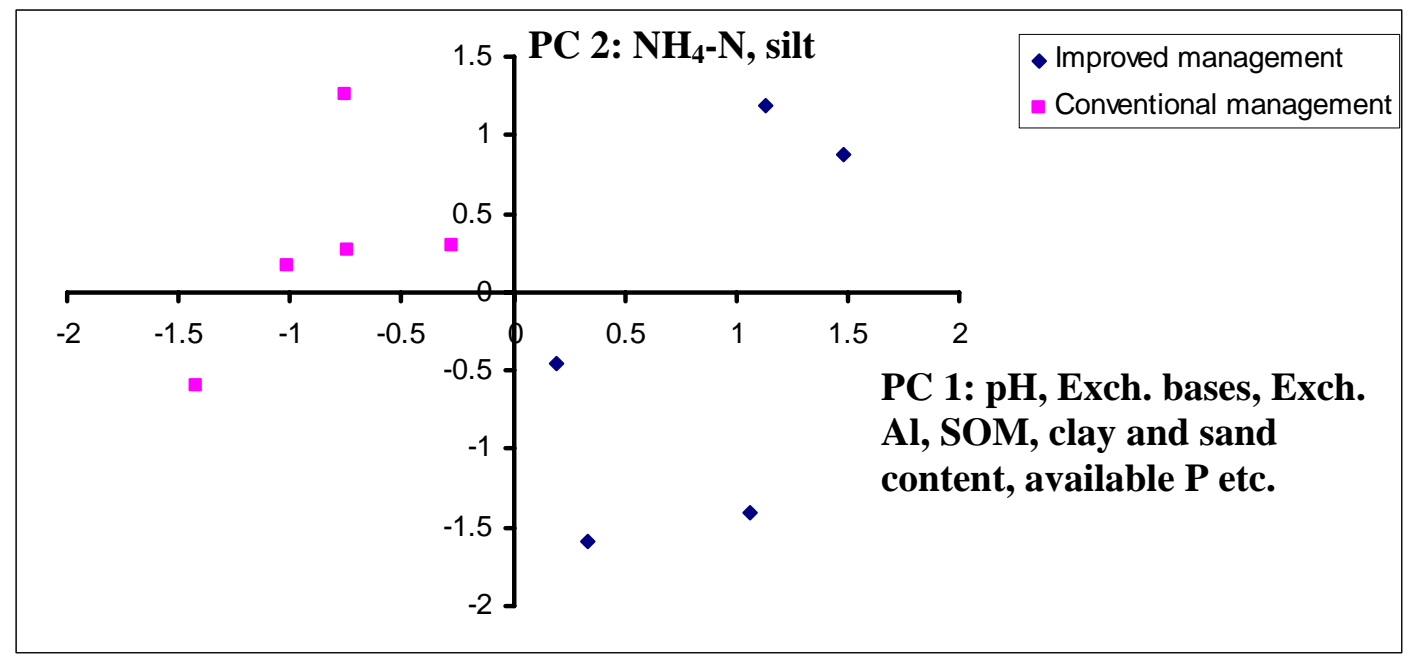

Figure 1. PCA ordination for the first two principle components (PC 1 and PC 2) for the soil analysis data.

On the other hand, most of the farmers (75\%) perceived that the use of improved FYM/compost and fertilization with combination of $\mathrm{N}, \mathrm{P}$ and $\mathrm{K}$ fertilizers resulted in decrease in soil hardness of their upland fields making the cultivation practices easier than before. However, others believed that there was no change in the soil hardness. The farmers with negative opinion on soil fertility and soil hardness improvement thought that their soils were too deteriorated and would need more time for the recovery of the fertility and good physical condition.

Change in productivity of upland crops: Productivity of major upland crops in the study area before and after adoption of 'improved FYM/compost' technology is compared in Table 4. A significant increase in productivity of three main upland crops, namely, maize (Zea mays L.) $(\mathrm{P}<$ 0.001), mustard (Brassica juncea L.) $(\mathrm{P}<0.01)$ and potato (Solanum tuberosum L.) $(\mathrm{P}<0.001)$ was observed after adoption. Better nutrient and crop management following the adoption of the new practice might be expected to have played a major role in increasing the productivity.

\section{Table 4. Change in productivity of major upland crops (mt ha-1)}

\begin{tabular}{lccc}
\hline Crop & $\begin{array}{c}\text { Before adoption of } \\
\text { improved practice }\end{array}$ & $\begin{array}{c}\text { After adoption of } \\
\text { improved practice }\end{array}$ & \% change \\
\hline Maize $(\mathrm{n}=68)$ & 1.5 & 2.0 & 27.4 \\
Mustard $(\mathrm{n}=68)$ & 0.4 & 0.5 & 21.9 \\
Potato $(\mathrm{n}=68)$ & 4.6 & 7.1 & 53.0 \\
\hline
\end{tabular}

Average productivity of maize, mustard and potato in Kavrepalanchok district was $2.45,0.98$ and $18.5 \mathrm{mt} \mathrm{ha}^{-1}$ respectively in 2004 (DADO 2005). The productivity after the adoption of improved practice as shown in Table 4 corresponds to the productivity in 2004. From the table it can be seen that the productivity of all the three crops after the adoption of new improved practice in the VDC was lower than the district average for the same season.

The increase in productivity can not be solely attributed to the effect of positive change in soil fertility since in many cases farmers commented that they were able to enjoy better harvest for the particular crop due to improvement in other aspects of crop management including increased use of 
improved and high yielding hybrid variety of maize, mustard and potato effective plant protection measures among others.

\section{CONCLUSION}

Soil fertility decline has been one of the main reasons for poor agricultural growth in Nepal in recent decades. Mid hills region has been worst hit by this problem because of its fragile geomorphology, steep topography and intense human pressure on land and forest resources. This situation is posing a threat to the sustainability of the agriculture system in the region. A number of factors are responsible for the decline in soil fertility. The three major factors often cited are accelerated soil erosion, increased use of acidifying fertilizers and reduced organic matter input into the soils. Many efforts are being made to avert the further worsening of the situation and restore the fertility. Organic matter based improved soil management practice is one of participatory approaches aiming at improving the soil fertility of upland soils in the mid hills of Nepal.

FYM and compost play a vital role in supplying a major fraction of plant nutrients and organic matter input into the soil in upland farming system of the mid hills. However, improper handling of preparation and field application procedures by the farmers cost substantial nutrient loss and result in poor quality of the FYM and compost. Moreover, there is a general tendency of farmers applying nitrogenous fertilizers only. This practice is believed to be responsible for the increased soil acidity and surface hardness. An improved soil management practice has been introduced to help solve above mentioned problems. This study compared the soil fertility of soils under improved soil management practice with that of prevailing conventional soil management practices and assessed the improved practice from farmers' perspectives.

Results of soil analysis showed higher fertility of soils under improved soil management practice than the soils under conventional management practices in terms of more favorable soil $\mathrm{pH}, \mathrm{T}-\mathrm{C}, \mathrm{T}$ $\mathrm{N}, \mathrm{CEC}$, exchangeable bases, mainly exchangeable $\mathrm{Ca}$ and $\mathrm{Mg}$, and exchangeable Al. Moreover, soils under improved practice have higher clay content than that of conventional practice which might have influence on the fertility of the both the soils.

A number of positive effects of the adoption of the improved practice were observed. Farmers believed that fertility of their upland soils had increased and that soil hardness had also reduced facilitating ease of cultivation. A significant increase in the productivity of major upland crops including maize (Zea mays L.), mustard (Brassica campestris, var. toria ), and potato (Solanum tuberosome L.) was found in farmers' interview. It should be, however, noted that other aspects of crop management such as use of hybrid seeds, plant protection measures and so on also played a role in increasing production.

Moreover, it is desirable to conduct a long term research on the effect of applying improved soil management practice on different soil types and land uses of the mid hills of Nepal to further ascertain the results obtained.

\section{REFERENCES}

Bray RH and LT Kurtz. 1945. Determination of total, organic, and available forms of phosphorus in soil. Soil Sci. 59:39-45.

Brown S. 1997. Soil fertility, nutrient dynamics and socio-economic interactions in the middle mountains of Nepal. 2004. PhD Thesis, interdisciplinary studies in resource 
management science, University of British Columbia, Vancouver, BC. In: Agricultural intensification and the impacts on soil fertility in the middle mountains of Nepal (S Westarp, H Shreier, S Brown and PB Shah, eds). Can. J. Soil Sci. 84: 323-332.

Brown S, H Shreier, PB Shah, and L. Lavkulich. 1999. Modeling of soil nutrient budgets: an assessment of agricultural sustainability in Nepal. Soil Use Manage 15:101-108.

Carson B. 1992. The land, the farmer and the future: A soil fertility management strategy for Nepal. ICIMOD Occasional Paper, No. 21. ICIMOD, Kathmandu, Nepal.

CBS. 2002. Statistical pocket book, Nepal. 2002. National Planning Commission Secretariat, Central Bureau of Statistics, Kathmandu, Nepal.

HMG/N. 2004. Statistical information on Nepalese agriculture 2003/2004. Agri-Business Promotion and Statistics Division, Ministry of Agriculture and Cooperatives, His Majesty's Government, Singha Darbar. Kathmandu.

Juo ASR and Franzluebbers. 2003. Tropical Soils: Properties and Management of Sustainable Agriculture. Ist Edn. Oxford University Press, Inc, New York.

Kyiogwom UB, BF Umaru and HM Bello. 1998. The use of indigenous knowledge in land classification and management among farmers in the Zamfara Reserve (Electronic version). In: Prospects of pastoralism in West Africa (I Hoffmann, ed). Giessener Beiträge zur Entwicklungsforschung, Reihe I (25):220-227.

Mulvaney RL. 1996. Nitrogen - Inorganic forms. In: Methods of soil analysis (DL Sparks et al., eds.) Part 3. SSSA Book Ser. 5. SSSA, Madison. WI. Pp. 1123-1184.

Neupane RP and GB Thapa. 2001. Impact of agro-forestry intervention on soil fertility and farm income under the subsistence farming system of the middle hills, Nepal. Agriculture, Ecosystems and Environment 84:157-167.

Pandey SP. 1996. Soil fertility and nutrient management. In: Sustainable management of soils in rainfed cropping systems in the mid-hills of Nepal, Compilation of Main Findings. Swiss Development Cooperation (SDC)/Nepal, Agricultural Project Services Centre (APROSC), Kathmandu, Nepal.

Paudel GS and GB Thapa. 2001. Changing farmers' land management practices in the hills of Nepal (Electronic version). Environmental Management 28(6):789-803.

Pierzynski GM, JT Sims and GF Vance. 1994. Soil environmental chemistry. Lewis Publishers, CRC Press Inc., USA.

Pilbeam CJ, SB Mathema, PJ Gregory, and PB Shakya. 2005. Soil fertility management in the mid-hills of Nepal: Practices and perceptions. Agriculture and Human Values 22:243-258.

Schreier H, S Brown, LM Lavkulich and PB Shah. 1999. Phosphorus dynamics and soil Pfertility constraints in Nepal. Soil Science 164(5):341-350.

Schreier H, PB Shah, and S Brown. 1995. Challenges in mountain resource management in Nepal: Process, trends and dynamics in a middle mountain watershed. Workshop Proceedings. International Development Research Center and International Center for Integrated Mountain Development, Kathmandu, Nepal. 
Turton CN, A Vaidya, JK Tuladhar and KD Joshi. 1995. Towards sustainable soil fertility management in the hills of Nepal. Chatham Maritime (Kent): Natural Resources Institute and Lumle Agriculture Center Pokhara.

Westarp S, H Shreier, S Brown and PB Shah. 2004. Agricultural intensification and the impacts on soil fertility in the middle mountains of Nepal. Can. J. Soil Sci. 84: 323-332. 